\title{
E-Learning Readiness Measurement in SMK Negeri DKI Jakarta
}

\section{Akbar Jaya, Ivan Hanafi, and Rina Febriana}

Vocational Education Program, State University of Jakarta, Jakarta, Indonesia

\section{Abstract}

The purpose of this study was to determine the readiness of e-learning (e-learning readiness) that is effective and would make graduates of DKI Jakarta Vocational High School (SMK) have employability skills so that SMK graduates are ready to work. This research can also be used as a reference by researchers to conduct further research. The study uses descriptive statistical analysis. Data collection was done by leading observations and interviews using a Likert scale. Data processing was done by measuring the e-learning readiness with Aydin \& tasci (2005) index model. The results of e-learning readiness research at SMK Negeri DKI Jakarta has a value index of 3.42, which indicates that e-learning readiness at SMK Negeri DKI Jakarta is ready for a

Corresponding Author:

Ivan Hanafi

ivan.hanafi@gmail.com

Received: 11 January 2019

Accepted: 14 February 2019

Published: 25 March 2019

Publishing services provided by Knowledge E

(c) Akbar Jaya et al. This article is distributed under the terms of the Creative Commons

Attribution License, which permits unrestricted use and redistribution provided that the original author and source are credited.

Selection and Peer-review under the responsibility of the 3rd ICTVET 2018 Conference Committee. little improvement to implement e-learning. There are several indicators of e-learning readiness that fall into the category of not ready but require preparation including signs of motivation, initiative, content, and interaction. Therefore, it is necessary to do better preparation for the implementation of e-learning so that e-learning is more effective and students can have employability skills in preparing graduates of SMK Negeri DKI Jakarta who are ready to work and have expertise in technology and information by using e-learning.

Keywords: e-learning, e-learning readiness, Vocational High School

\section{Introduction}

Vocational High Schools (SMK) are secondary education that prepares students especially to work [1]. Vocational graduates prepared for three things, namely:

1. Vocational High School are ready to work in the business and industrial fields (DUDI).

2. Vocational High School prepared to be able to continue their education to the next level through vocational education channels to improve expertise in certain fields.

3. Vocational High School are prepared for entrepreneurship. 
Vocational School prepares students to meet the target after graduation, namely Work, Continuing Education and Entrepreneurship, this is the responsibility of various aspects including curriculum, educators, and educational institutions. According to Charles Prosser in 16 Principles of Vocational Education, one of which is vocational education will be efficient in proportion as the environment in which he must subsequently work, from one of the principles states that vocational education will be useful if the climate trained as an environmental replica where later it will work. Vocational graduates are also prepared to have employability skills as an ability to actively adjust someone to a job.

The results of research [2] the current state of vocational high school shows that SMK graduates have not produced superior human resources and have creative, innovative, flexible (adaptability), technology literate, skilled, and has multiple intelligence. Data from [3] shows that most vocational school graduates experience unemployment with up to $10 \%$ of the 7.01 million unemployed people. This is very unfortunate considering that SMK graduates are prepared to be ready to work, but empirical data shows the opposite, that most vocational school graduates become unemployed. One factor in the occurrence of unemployment can occur because SMK graduates are not by the competencies of the business world and industry.

Vocational Schools have several fields of expertise, one of which is information and communication technology. In this field, prioritizing digital technology is all that is done in this field using computers and the internet. Based on interviews with several companies in the area of information and communication technology, information obtained that companies utilize email-based information systems and use website-based elearning for corporate research and development purposes. This can be referred to as employability skills that need to be prepared for graduates of vocational schools in order to have the expertise to run information systems that use computers and the internet. As an effort to gain experience and employability skills need to be supported by using learning models utilizing computers and internet networks. The learning model is e-learning.

The model of e-learning [4] is necessarily a form of traditional education that is poured into digital format and presented through Information Technology. Before the implementation phase of e- learning requires measurement of readiness in implementing e-learning learning models or commonly called e-learning readiness.

E-learning readiness [5] illustrates how prepared an organization is in several aspects to implement e-Learning. E-learning readiness as a stage to evaluate not only the readiness of the teacher and students but the readiness of the organization or institution 
itself. E-learning readiness is needed to deal with obstacles or barriers in its implementation. There are seven obstacles in the implementation of e-learning [6] including:

1. Personal Barrier, including time management issues, problems regarding language and attitudes towards e-Learning

2. Learning Style Barrier includes learning preferences

3. Situational Barrier, including learning duration and interruption in learning

4. Organizational Barrier, including problems in corporate culture, lack of time for study, interpersonal barriers, limited availability of online subjects, difficulties in registration, lack of awareness and failure to involve employees in planning or decision making

5. Technological Barrier, including quality Learning Management System (LMS), connectivity problems, lack of training, navigation problems, limited technical support, data loss and inability to transfer data

6. Content Barrier, including student expectations of lessons, relevance of experiences, content that is not specific to participants, poor quality content and poor evaluation / evaluation system Instructional Barriers include lack of progress reports and feedback, limited student involvement, design limited instructional, limited reference materials, limited access and navigation problems for multimedia use, inconsistent instruction, excessive information, lack of instructor/interaction and poor coordination.

The e-learning readiness model generated from studies and literature studies includes:

1. [7] classified e-learning readiness into eight categories including:

(a) Psychological readiness considers the individual's perspective on the influence of e- learning initiatives. This is the most critical factor that must reviewed and has the highest chance of sabotaging the implementation process

(b) Sociological readiness, consider the interpersonal aspects of the environment in which the program will implement.

(c) Environmental readiness, considering the operation of significant forces on stakeholders, both inside and outside the organization.

(d) Human resource readiness, considering availability and design of human resource support systems. 
(e) Financial readiness, considering the size of the budget and the allocation process.

(f) Technological skill (aptitude) readiness, considering technical competencies that can be observed and measured.

(g) Equipment readiness, consider ownership of the appropriate equipment.

(h) Content readiness, consider learning content and learning objectives.

2. [8] classifies e-learning readiness into eight dimensions including:

(a) Institutional / Organizational Dimensions

(b) Management Dimensions

(c) Dimensions of Technology

(d) Pedagogical Dimensions

(e) Ethics Dimensions

(f) Display Design Dimensions

(g) Supporting Dimensions

(h) Evaluation Dimensions

3. [9] classifies aspects of e-learning readiness in 5 factors including:
(a) Self-competence
(b) Self-directed learning
(c) Motivation
(d) Financial
(e) Usefulness

4. [10] classify e-learning readiness into 4 factors including:

(a) Technological factors (This factor considers ways to streamline the adaptation of technological innovations, namely e-learning in a school or organization)

(b) factors of innovation (This factor considers the experience of human resources in schools and organizations in adopting an innovation, e-learning

(c) Human factors (This factor examines the characteristics of human resources in schools and organizations)

(d) Self-development factors (This factor considers the trust of schools and organizations towards self-development in the application of e-learning). 
Based on the problems presented earlier, SMK graduates must be prepared to have DUDI competencies, one of them is by having Employability Skills so that the number of unemployed SMK graduates decreases and is ready to work to support this by using e-learning learning models that can help students to improve understanding and competence. up to having the employability skills needed in DUDI. Besides, that educators must play an active role in preparing e-learning learning models effectively.

Analysis of the level of readiness measurement (e-learning readiness) is needed before e- learning is implemented or has implemented, but the measurement of the level of e-learning readiness in the State Vocational School of DKI Jakarta has not been carried out. Therefore the researchers researched the measurement of e-learning readiness by using a sample in several SMK Negeri DKI Jakarta. The purpose of this study was to determine the readiness of e-learning (e-learning readiness) which is useful and graduates of SMK who have employability skills so that SMK graduates are ready to work. The research will also be used as a reference by researchers to conduct further research.

\section{Methods and Equipment}

\subsection{Methods}

This research uses descriptive statistical analysis. Data collection was carried out by observation and interviews using a Likert scale for teachers of the State Vocational School in DKI Jakarta. Data processing uses the e-learning readiness model. After making observations and interviews, the measurement of e-learning readiness with the Aydin \& tasci index model. Observations and interviews were conducted to find empirical data about e-learning readiness in DKI Jakarta Vocational High School which will use as a reference by researchers to do further research.

\subsection{Equipment}

This research develops the framework by classifying the components obtained from related literature and analysis as described in Table 1. After categorizing the factors of e-learning readiness, the elements examined are as shown in Table 2 as follows:

Variables and indicators of e-learning readiness converted into a questionnaire with statements on each indicator. The e-learning readiness questionnaire uses a Likert scale in answering the explanations given. 
TABLE 1: E-Learning Readiness Factors Mapping.

\begin{tabular}{|l|l|c|c|c|c|c} 
No. & E-learning Readiness Factors & Capnick & $\begin{array}{c}\text { Badrul } \\
\text { Khan }\end{array}$ & $\begin{array}{c}\text { Farid } \\
\text { Alem } \\
\text { dkk }\end{array}$ & $\begin{array}{c}\text { Aydin } \\
\text { dan } \\
\text { Tasci }\end{array}$ & Total \\
\hline 1 & Psychology & $\square$ & $\square$ & $\square$ & $\square$ & 4 \\
\hline 2 & Social & $\square$ & - & $\square$ & - & 2 \\
\hline 3 & Innovation & - & $\square$ & - & $\square$ & 2 \\
\hline 4 & Human Resources & $\square$ & - & $\square$ & $\square$ & 3 \\
\hline 5 & Finance & $\square$ & - & $\square$ & - & 2 \\
\hline 6 & Technology & $\square$ & $\square$ & - & $\square$ & 3 \\
\hline 7 & Facilities and infrastructure & $\square$ & - & - & - & 1 \\
\hline 8 & Organizational Culture & $\square$ & $\square$ & - & - & 2 \\
\hline 9 & Management & - & $\square$ & - & - & 1 \\
\hline 10. & Content or Material & $\square$ & $\square$ & $\square$ & - & 3 \\
\hline
\end{tabular}

TABLE 2: Variables and Indicators E-Learning Readiness.

\begin{tabular}{|l|l|l|}
$\begin{array}{l}\text { No. } \\
1\end{array}$ & $\begin{array}{l}\text { Variable } \\
\text { Psychology }\end{array}$ & $\begin{array}{l}\text { Indicator } \\
\text { Motivation } \\
\text { Initiative }\end{array}$ \\
\hline 2 & Human Resources & $\begin{array}{l}\text { Competence } \\
\text { Self-development } \\
\text { Hardware }\end{array}$ \\
\hline 3 & Technology & $\begin{array}{l}\text { Software } \\
\text { Network } \\
\text { contents of the material }\end{array}$ \\
\hline 4 & Content or Material & Interaction \\
\hline
\end{tabular}

The Likert scale [11] is used to measure attitudes, opinions, and perceptions of a person or group of people about social phenomena. There are five choices of answers on a Likert scale ranging from "strongly disagree" to "strongly agree." But there are several alternative answers on the Likert scale, namely: "no," "just a few," "half," "almost all," and "all."

Measurement of the level of readiness level of e-learning (e-learning readiness) in this study using an index model adapted from [10], namely:

1. Not ready needs a lot of work to implement e-Learning (Index $1-2.59$ )

2. Not ready needs some work to implement e-Learning (Index 2.6 - 3.39)

3. Ready but needs a few improvements to implementing e-Learning (Index 3.4 4.19)

4. Ready to go ahead to implement e-Learning (Index 4.2 - 5). 


\section{Results}

Based on the results of observations and interviews in 3 (three) DKI Jakarta Vocational Schools that implement e-learning in subjects in schools where the questionnaire data that has been filled in by respondents are grouped into tables according to variables and indicators on the e-learning component readiness. The measurement results using the e-learning readiness model obtained the following data:

1. In the psychological variable, the average index of e-learning readiness with each indicator is the motivation of 2.6 (not ready but needs some preparation) and the initiative indicator 2.6 (not ready but needs some preparation).

2. In the variable human resources (HR) with each indicator that is a competence of 3.6 (ready but needs a little improvement) and a self-development indicator of 3.5 (ready but needs a little improvement)

3. In the technology variable with each indicator that is a hardware indicator of 4.2 (ready for implementation), a software indicator of 4.2 (ready for implementation), and a network indicator of 4.4 (ready for implementation)

4. In the variable content and material of each indicator, the content indicator is 3.2 (not ready but needs some preparation) and the interaction indicator is 3.3 (not ready but needs some preparation).

\section{Discussion}

From these data, the average of the e-learning readiness index of DKI Jakarta State Vocational School is 3.42 which is in the ready category but requires a little improvement. Based on the e- learning readiness model in the State Vocational School of DKI Jakarta shows the category is not ready yet but requires some preparation on several variables including psychology variables of 2.6 and variable content and material of 3.25. Whereas for the HR and technology variables showed a value of 3.55 and 4.27 in the ready category but needed a little improvement.

Psychology categories on motivational and initiative indicators and content and material variables on content and interaction indicators are needed evaluation in fulfilling e-learning implementation readiness. Therefore the researcher will continue research on the evaluation of e- learning by using the model of HOT (Human, Organization, Technology) FIT in State Vocational Schools in Jakarta. So that it can improve e-learning readiness which has an impact on the effective use of e-learning learning models in 
schools. For students of SMK Negeri DKI Jakarta to have employability skills that make graduates of SMK Negeri DKI Jakarta ready to work.

\section{Conclusion}

Based on the results of the research conducted it can conclude that the level of elearning readiness at the State Vocational School of DKI Jakarta gets an index value of 3.42 which indicates that e-learning readiness in SMK Negeri DKI Jakarta is ready but needs some improvement to implement e-learning.

Indicators included in the category are not ready (not ready) but need preparation to implement e- learning, namely indicators of motivation, initiative, content, and interaction. Therefore it is necessary to do better preparation for the implementation of e-learning so that e-learning is more effective and students can have employability skills in preparing graduates of SMK Negeri DKI Jakarta who are ready to work and have expertise in technology and information by using e-learning.

\section{Acknowledgement}

The authors would like to thank their colleague for their contribution and support to the research. They are also thankful to all the reviewers who gave their valuable inputs to the manuscript and helped in completing the paper.

\section{Conflict of Interest}

The authors have no conflict of interest to declare.

\section{References}

[1] Law of the Republic of Indonesia Number 20. (2003). Sistem Pendidikan Nasional. Jakarta.

[2] Slamet, P. H. (2013). Pengembangan SMK Model untuk Masa Depan. Cakrawala pendidikan, pp. 14-26.

[3] The Central Statistics Agency (BPS) Republic of Indonesia (2017).

[4] Darmawan, D. (2011). Teknologi Pembelajaran. Bandung: PT Remaja Rosdakarya. 
[5] Fariani R. I. (2013). Pengukuran Tingkat Kesiapan E-Learning (E-Learning Readiness) Studi Kasus pada Perguruan Tinggi ABC di Jakarta. Seminar Nasional Aplikasi Teknologi Informasi (SNATI). pp. 1-7.

[6] Mungania, P. (2003). The seven e-learning barriers facing employees. Research final report of the masie center of e-learning consortium. University of Louisville, p. 8.

[7] Priyanto. (2008). Model E-Learning Readiness Sebagai Strategi Pengembangan ELearning. International Seminar Proceedings on The Information and Communication Technology (ICT) in Education, pp. 267-275.

[8] Khaerudin. (2014). Penilaian kebutuhan pemanfaatan e-learning. Jurnal Parameter. Vol. 25, No. 2, pp. 62-72.

[9] Alem, F. Dkk. (2016). Measuring e-Learning Readiness Concept: Scale Development and Validation Using Structural Equation Modeling. International Journal of eEducation, e- Business, e-Management and e-Learning. Vol. 6, No. 4, pp. 193-207.

[10] Aydin, C. H. \& Tasci, D. (2005). Measuring Readiness for eLearning: Reflections from an Emerging Country. Educational Technology \& Society. Vol. 4, No. 8, pp.244- 257.

[11] Sugiyono. (2011) Metode Penelitian Kuantitatif dan Kualitatif dan $R \&$ D.Bandung: CV Alfabeta. 